\title{
Feeding Patterns Of Resident Fishes In Thai Mangrove Estuary: Implications For Conservation And Sustainable Use Of Coastal Resources
}

\author{
Siraprapha Premcharoen ${ }^{1}$
}

\begin{abstract}
Seasonal dietary patterns, dietary attributes and trophic guild structure of 12 resident fishes inhabiting the Mae Klong mangrove estuary, inner Gulf of Thailand were examined. Relative diet composition was described by the points method. Measurements were made also of gut fullness, vacuity index and diet breadth. Interspecific variations in diet were described by Bray Curtis coefficients and grouped, based on similarity coefficients, into eight feeding guilds. Of these, most diets were dominated by sergestid shrimp, zooplankton, phytoplankton, benthic invertebrates, shrimp, polychaete, fish and insect. Zooplankton was the most common dietary item by all fishes examined $(25.2 \%)$. Food intake was low for most fish with fullness values of 0.58 to 2.07. Vacuity index ranged from 4.70 to 58.23 among species, with indices for most species $>20$. Overall diet breadth was relatively low among species and ranged from 0.13 for Aspericorvina jubata to 0.46 for Dendrophysa russelli. There was a clearly significant difference in the percentage composition of food items among seasons $(\mathrm{P}=0.001)$. The results from this study can serve as a reference for feeding ecology of fish in the Mae Klong estuary and in sustainable use and management of fisheries resources in the area.
\end{abstract}

Keywords: seasonal pattern, dietary attribute, trophic guild, resident fishes, Thai mangrove

\section{Introduction}

Mangrove habitat is often characterized by high densities of juvenile fishes, creating a complex food web (Lugo and Sedaker, 1974; Ikejima et al., 2003). Epifaunal and infaunal organisms are an abundant, high quality food resource for fishes and crustaceans in mangroves (Sasekumar et al., 1992). Fish are often at the top of food chains in estuarine systems. Nevertheless, they are a trophically diverse group, encompassing species of different sizes and diverse feeding strategies (Abrantes and Sheaves, 2009). Although tropical coastal ecosystems in Southeast Asia are important habitats for fish, there has been relatively few studies on community and feeding ecology of these ecosystems (Chong et al., 1990; Poovachiranon and Satapoomin,1994; Sasekumar et al., 1994; Hajisamae et al., 2003, 2004, 2006). Feeding ecology and trophic organization of fish assemblage are fundamental tools which provide useful information in positioning of fishes in the food web in their environment and in formulating 
management strategy options in multi-species fisheries (Hajisamae and Ibrahim, 2008; Hajisamae, 2009).

The Mae Klong estuary located in the coastline of Samut Songkhram Province, western part of the inner Gulf of Thailand, may be explained partly by the intensive human exploitation of the estuary, through shellfish (blood cockle and horse mussel) farming (Alongi, 2002). There may also be impacts in the estuary due to wider fishing activity offshore in the Gulf of Thailand (Christensen and Pauly, 1998) because many commercial species breed in the estuary and use it as a nursery ground. These are large losses of primary production due to hydrodynamic exchanges (Le Pape et al., 1999).

In order to understand the food webs, it is necessary first to understand the trophic relationships of the individual organisms. This is accomplished by analyses of diets and arrangement of the organisms into a trophic sequence. Seasonal changes in the diet of each fish species should also be considered as they may have effects on the ecological interactions among fishes (Xie et al., 2000). So, the objectives of this study are to (a) investigate dietary composition and feeding attributes of 12 dominant resident fish species inhabiting the Mae Klong mangrove estuary (b) examine trophic guilds of these fishes in general (c) evaluate the effect of seasonal patterns on trophic guilds.

\section{Materials and methods}

\subsection{Sampling of the fish fauna and stomach content analysis}

All field studies were conducted at Mae Klong estuary, intertidal mangrovefringed (Figure 1). Six sampling sites covering different mangrove types were carried out seasonally: December to February (dry season), March to May (hot season), and June to November (rainy season), between December 2005 and November 2006, using a pushnet. All collections were made in both day and night at high tide, so that the feeding habits of fish utilizing littoral habitats could be properly assessed. A total of 63 species was collected. Of these 12 resident species (according to Vidthayanon and Premcharoen, 2002) were selected for the present study. Fish caught were preserved immediately in $10 \%$ buffered formaldehyde. Diets were derived from an analysis of the stomach contents of fishes covering a size range corresponding to the adult stage. All items were identified to the lowest possible taxonomic level. The percentage volume of major gut items was estimated by using the points method of Hynes (1950). In this method, the contents of each stomach sample were taken as unity and the items expressed as a percentage of the total volume by visual inspection on a 4-point scale. The points, and the percentages they represent are as follows: 4(75-100\%), $3(50-75 \%), 2(25-50 \%)$ and 1 (up to $25 \%$ ). Points for each food item were rescaled to give the percentage composition of different food items in the diet. Empty stomachs or stomachs with almost fully digested contents were excluded.

\subsection{Treatment of data}

The raw data were analyzed for:

Volumetric contribution $(\% \mathrm{~V})$ : the percentage contribution to the volume of all dietary items present in each of non-empty stomachs (Platell and Potter, 2001).

Trophic indices: the relative level of dietary specialization of different fish species (Hyslop, 1980). The indices using in the present study included:

Gut fulless (FL) is the weight of the stomach content as a percentage of the gutted weight of the fish. 


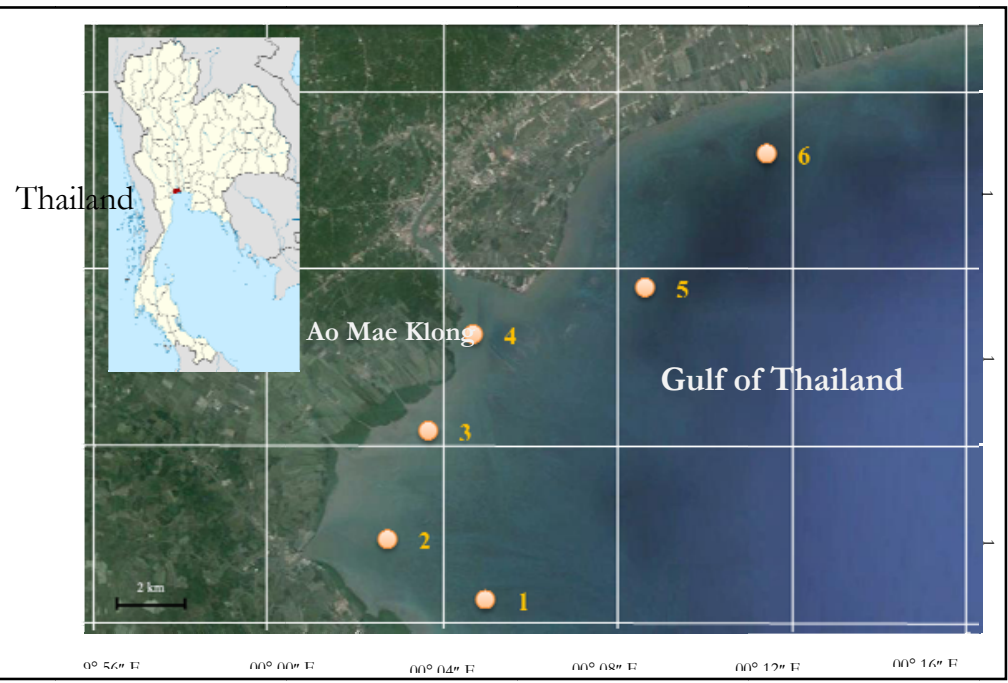

Figure 1. Mae Klong estuary, inner Gulf of Thailand, showing location of sites (O) from which fish samples were collected.

Vacuity index (VI) is the number of empty stomachs as a percentage of the total number of stomachs examined.

Diet breadth $(B \imath)$ is calculated using Levin's standardized index (Krebs, 1989; Labropoulou \& Papadopoulou-Smith, 1999), with volume value data. Hurlbert's formula (1978) was applied to standardize the trophic niche measure (ranging from 0 to 1), according to the formula;

$$
B i=\left(\frac{1}{n-1}\right)\left(\left(\frac{1}{\sum_{i, j=1}^{n} P_{i j}^{2}}\right) 1\right.
$$

Where $B i=$ Levin's standardised index for predator $i ; P_{i j}=$ proportion of diet of predator $i$ that is made up of prey $j ; n=$ number of prey categories. Diet breadth values were arbitrarily set at the following levels: high $(>0.6)$, intermediate $(0.4-0.6)$ or low $(<0.4)$ (Novakowski et al., 2008).

\subsection{Data analysis}

To test whether dietary composition of the 12 fish species differ from each other, the guts of each species were separated into groups of dietary sample. To assess the trophic attributes of these 12 fish species, a method of volumetric contribution $(\% \mathrm{~V})$ including vacuity index, gut fullness value and diet breadth were calculated.

To construct general trophic guild, mean relative composition of food items was square root transformed and a similarity matrix using a Bray Curtis similarity indices was constructed and a cluster dendrogram using the software package PRIMER-v5 (Clarke and Warwick, 2001). A group of species falling in the same cluster was test for difference by analysis of similarities (ANOSIM) at $p=0.001$. Once ANOSIM's significance was found and $R>0.25$, the similarity percentage (SIMPER) was used to determine which items typified the diets of particular species and made the greatest contribution to any dissimilarity between species (Platell and Potter, 2001). Results from SIMPER, together 
with the raw data of food composition, were used to assess the robustness of the trophic group prior to constructing the overall trophic guild in Mae Klong estuary.

To determine seasonal variability among trophic guilds, the average seasonal contribution of each food item of all species combined was examined. Bray Curtis similarity indices were computed and hierarchical agglomerative clustering using groupaverage linking were performed on the resulting similarity matrices using the software package PRIMER-v5. The results of hierarchical agglomerative clustering were subjected to a non-parametric multidimensional scaling (nMDS). A one-way analysis of ANOSIM at $p=0.001$ was performed on the similarity matrices to test whether the dietary samples of different species were different by season. Once the significant difference was detected, the similarity percentage (SIMPER) was used to determine which dietary items make the greatest contribution to the similarity.

\section{Results and Discussion}

\subsection{Food and dominant food types}

Of the 5,780 stomachs examined, 4,281 (74.07\%) contained food and 1,499 $(25.93 \%)$ stomachs were empty. Prey items in the fish stomachs were usually digested and could not be identified to species. Of the 12 fish species, zooplankton formed the most abundant food $(25.2 \%)$ in diet compositions, followed by benthic invertebrates $(16.4 \%)$ and fish $(14.0 \%)$ (Table 1$)$.

A wide variety of foods was taken by Nemapteryx macronotacantha which consumed large numbers of polychaetes $(41.5 \%)$. No phytoplankton and other plant tissue found in the diets. This supports the study of Wichitwarakhun (2001) who found that major benthic groups in the Mae Klong estuary were polychaetes, crustaceans and gastropods, and also revealed that sediment characteristics, topography, tidal period, organic content, plant biomass, and mangrove forest structure were major factors determining species composition and distribution of the benthic community in the area. The diets of Liza tade showed the clear dominance of phytoplankton $(48.3 \%)$ and detritus $(32.8 \%)$ in compositions and these persisted in all seasons. Sergestid shrimp and zooplankton formed a minor part $(<2 \%)$. They were the only fish with relatively high percentages of phytoplankton and detritus. Blaber (1985) stated that in all southeast African estuaries, the most numerous fishes are the iliophagous species (mainly mullet) and that detritus, together with epipsammic algae and periphyton, provide a major energy input into the fish community. Organic detritus is a key food item for most fishes and has an important role in estuarine food webs (Darnell, 1961).

Zooplankton was the main component of the diet of Aspericorvina jubata (76.2\%). Many prey items were also found but $<10 \%$ of each. Prey items of sciaenids vary among groups, depending on their mouth characteristics (Yap et al., 1994). Sciaenids with terminal mouths usually feed in mid water, whereas those with subterminal mouths feed at the benthic surface. These feeding habits are likely to reduce food competition between the two groups. Eleutronema tetradactylum fed mainly on sergestid shrimp (40.1\%). This agrees with the study of Sudara et al. (1994) in the mangrove area of Samut Songkharm, Thailand. They showed that this area is famous for shrimp paste production from those of the mysid groups, especially the sergestid shrimp (Acetes erytraeus), and could be collected all year round. Salini et al. (1998) stated that this species was one of the three main predators (with Polydactylus sheridani and Lates calcarifer) in the Norman River Estuary, Australia. Juvenile fish formed the major diet in Strongylura strongylura (66.5\%). 
Sergestid shrimp, polychaete and shrimp were also presented. Insect, benthic invertebrates and zooplankton were also found in very small numbers $(<4 \%)$ in the diets. Whilst juvenile fish and insect formed an important component diet in Hyporhamphus limbatus (66.2\%).

\subsection{Dietary attributes}

Details of trophic attributes are illustrated in Table 1. For each of 12 fish species, with 4,281 stomachs were examined, stomach fullness (FL) for most species < 1.5 and ranged between 0.58 for Escualosa thoracata and 2.07 for Aspericorvina jubata, with most of them falling between 1 and 1.5. Vacuity index (VI) ranged from 4.70 to 58.23 among species, with indices for most species $>20$. Overall diet breadth was relatively low among species and ranged from 0.13 for Aspericorvina jubata to 0.46 for Dendrophysa russelli.

Table 1. Trophic indices and relative composition by volume of food of 12 fish species collected in Mae Klong estuary between December 2005 and November 2006; VI Vacuity index, FL mean gut fullness, No. Fl total number of food item, $B_{i}$ diet breadth (Note: Ben=Benthic invertebrates, Det=Detritus, Fis =Fish, Ins=Insect, Phy=Phytoplankton, Pol=Polychaete, Ser =Sergestid shrimp, Shr=Shrimp, Zoo= Zooplankton)

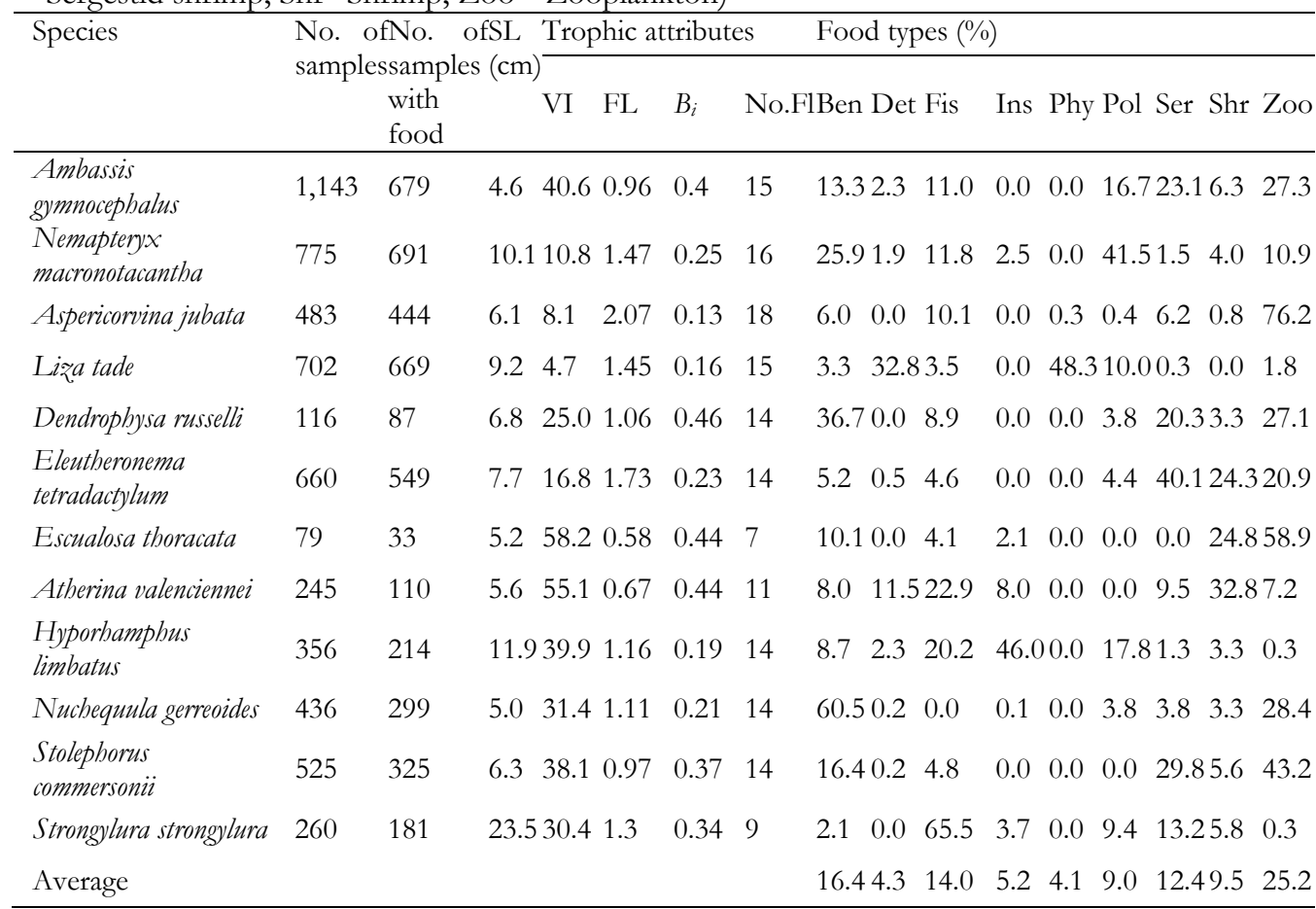

Results indicated that fishes have high food intake and feed on a specific range of food types. All species are specific feeders $(B i<0.60)$, relying on particular food types or low prey diversity. Variation of trophic attributes and diet composition of most fishes examined indicate that most of them are omnivorous, having different nutritional requirements and adopting different feeding strategies. However, the exact of mechanisms and reasons for individual of specialization remain unknow; it is likely 
related to the presence of functional trade-offs, either morphological, behavioral or physiological, e.g. learning in searching and handing prey, or in avoiding predation risk (Hammerschlag et al., 2010).

\subsection{General trophic guild}

A total of 4,281 fish stomach contents from 12 fish species occurring within the Mae Klong estuary observed for the trophic guild analysis. The grouping of major preys of fishes can be broadly categorized into eight different dietary guilds (Figure 2). The largest guild in terms of species, comprising of four species (33.3\%); which were grouped as zooplankton feeders, two species were grouped as benthic feeders and the left species were grouped of one individual as polychaete, sergestid shrimp, phytoplankton, shrimp, insect and fish.

Classification of the fishes into the feeding guilds provided clear associations between the different groups and ecosystem characteristics that offered insight into the potential trophic interactions in the area. Copepods, amphipods and mysids were the preferred prey of the zooplankton-feeding guild of the Mae Klong estuary, as previous studies in other estuarine environments have also shown (Boonruang et al., 1994; Sudara et al., 1994; Baldó and Drake, 2002; Boondao, 2006). Zooplankton densities in estuaries are strongly associated with river flow through the introduction of nutrients and the stimulation of phytoplankton growth (Wooldridge, 1999). For several of the zooplankton-feeding species, feeding preferences changed; mysids replaced copepods progressively in the diet of postlarva and juvenile fish as they grew (Baldó and Drake, 2002). Therefore, size and availability of prey seem to be the principal factors in determining the trophic guild structure of the small-sized fish assemblage studied in the Mae Klong estuary.

\subsection{Seasonal pattern of trophic guilds}

All the food groups showed seasonal variations in the gut contents of fish and showed a clearly significant difference in the number of food types found among three seasonal groups (Global $R=0.826, P=0.001$ ) (Figure 3). Results of SIMPER for the percentage contribution of each food groups to the guild formation in different seasons are summarized in Table 2. In dry season, fishes were classified into five trophic groups (Global $R=0.777, P=0.001)$. SIMPER showed that the first group (G1) fed predominantly on a combination of shrimp, sergestid shrimp and fish $(68.82 \%)$. The second group (G2) fed entirely on shrimp (100\%), third group (G3) and fourth group (G4) consumed benthic invertebrates $(72.39 \%)$ and insect $(77.35 \%)$ respectively. The last group (G5) made a contribution of phytoplankton (42.12\%) and detritus (38.18\%) in gut contents.

In hot season, fishes were classified into four trophic groups (Global $R=0.761$, $P=0.001)$. The first group (G1) fed on a contribution of fish $(43.47 \%)$, zooplankton $(19.25 \%)$, and benthic invertebrates $(18.40 \%)$. Zooplankton and benthic invertebrates formed together in the group G2 (91.57\%). The third group (G3) had only one food item, zooplankton (96.57\%). The group G4 comprised of $44.31 \%$ of phytoplankton and $31.29 \%$ of detritus. 


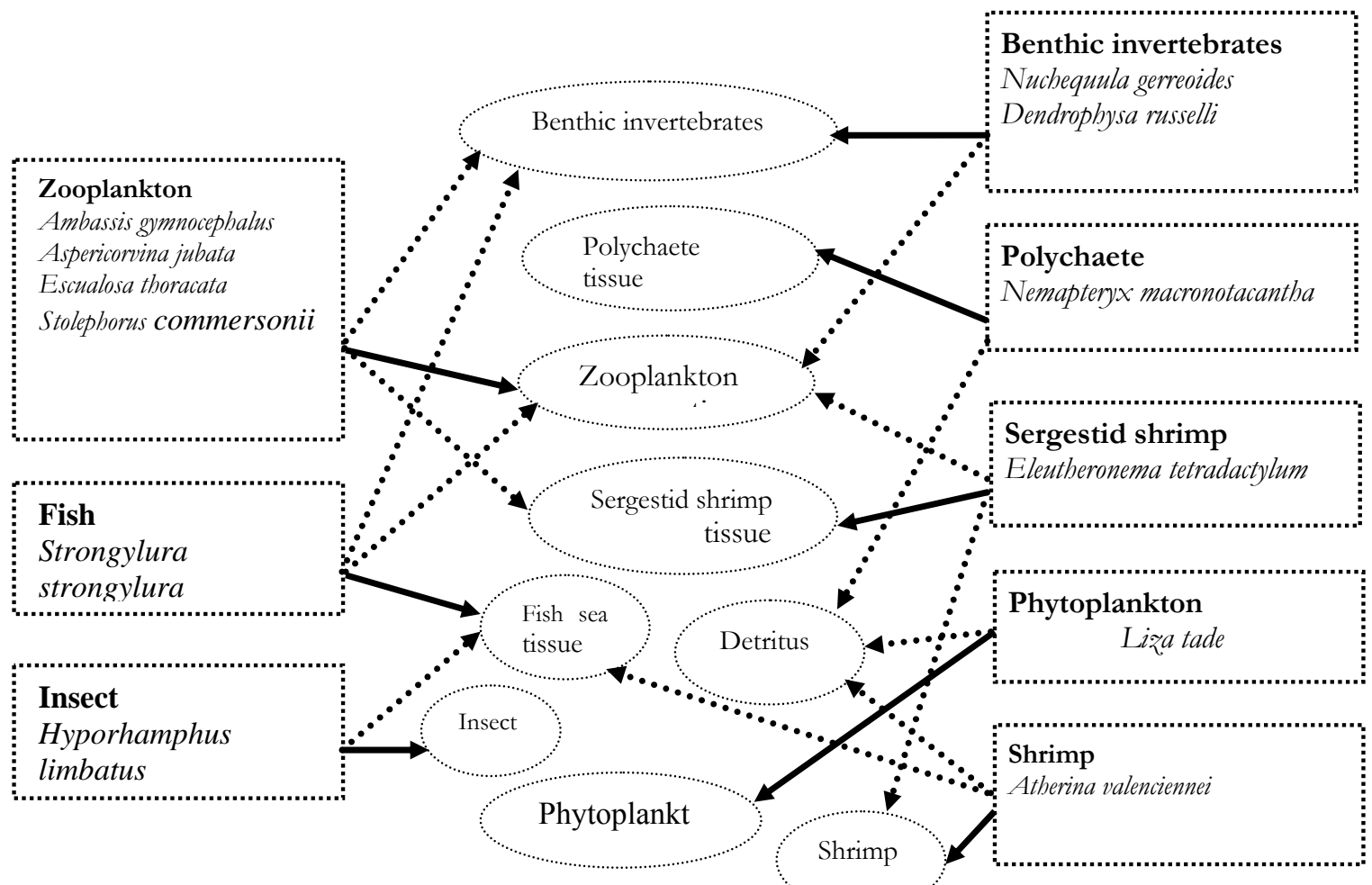

Figure 2. General trophic guild of fishes collected in Mae Klong estuary between December 2005 and November 2006. Thick lable $=$ major food type, thin lable $=$ minor food type. $($ ANOSIM Global R $=0.823, P=0.001)$

Trophic guild in rainy season was categorized into four main groups (Global $R=0.944$, $P=0.001$ ). The first group (G1) had various food items with the combination of fish, polychaete and benthic invertebrates (73.06). The group G2 had a combination of insect $(59.09 \%)$ and zooplankton (36.36\%). Phytoplankton formed the great contribution of group G3 (62.13\%), whilst the group G4 fed 100\% of insect.

Seasonal guilds in the Mae Klong estuary varied from four to five. Major food types including zooplankton, benthic invertebrates and fish. Seasonal changes in food availability may be caused by changes in the habitat available for foraging, changes resulting from the life history patterns of food organisms and changes caused by the feeding activities of the fish themselves (Wongchinawit, 2007). The availability of prey for juvenile fishes in the Mae Klong estuary would also increase during the hot and rainy seasons, since crustacean larvae were most abundant at this time in other mangrove areas of Thailand (Boonruang et al., 1994; Boonruang and Satapoomin, 1997). Zooplankton was also formed in greatest abundance in hot season which copepod and diatoms were dominated prey items in February and nematode as the main prey items in May (Sribyatta, 1996). 

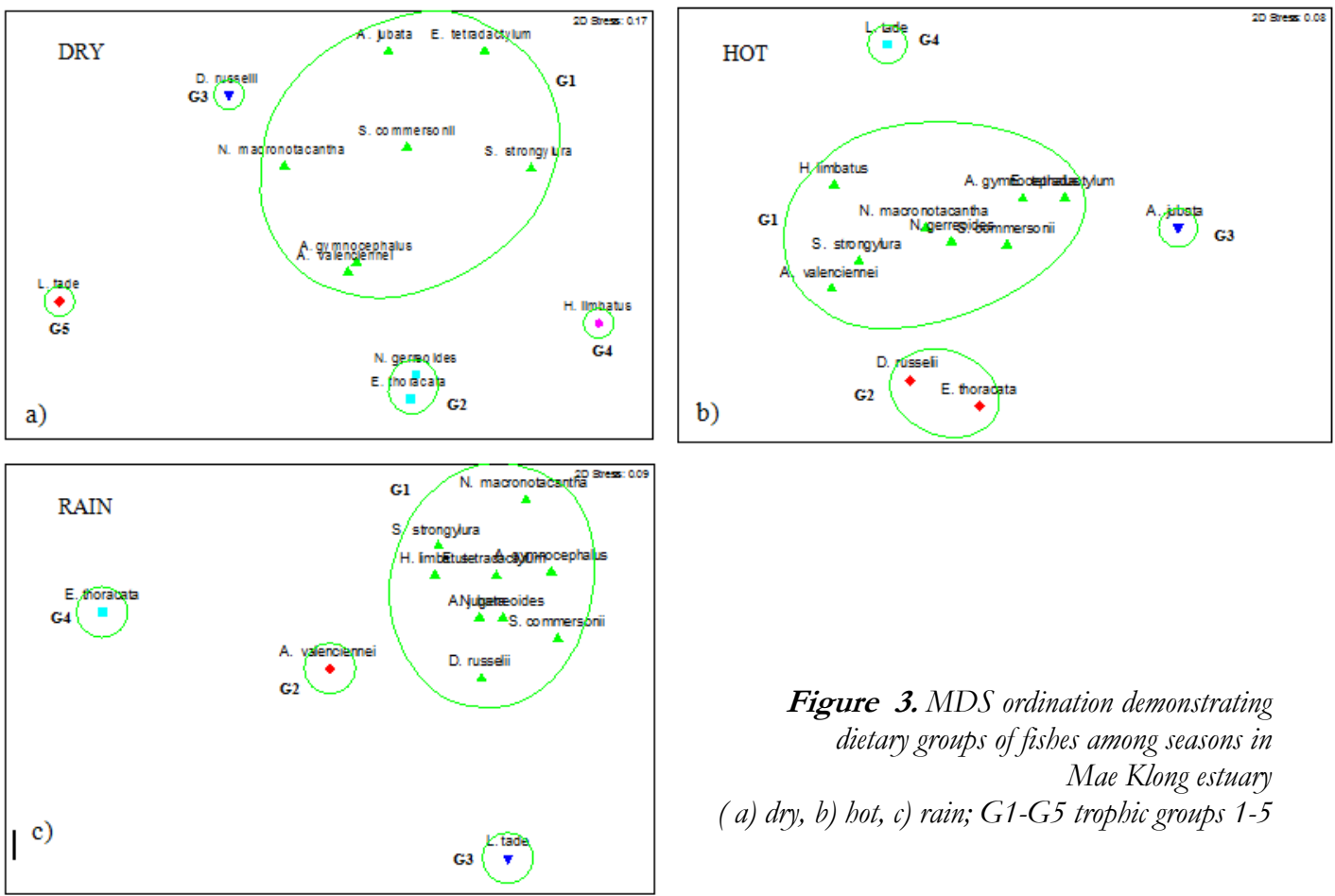

Figure 3. MDS ordination demonstrating dietary groups of fishes among seasons in Mae Klong estuary (a) dry, b) hot, c) rain; G1-G5 trophic groups 1-5

Table 2. Summary results of similar percentage analysis (SIMPER) on the contribution of major food items in the formation of trophic guilds during different seasons in Mae Klong estuary (G1G5= trophic guilds 1-5)

\begin{tabular}{|c|c|c|c|c|c|c|c|}
\hline Seasons & $\begin{array}{l}\text { Trophic } \\
\text { guilds }\end{array}$ & Food items & $\begin{array}{l}\% \\
\text { contribution }\end{array}$ & Seasons & $\begin{array}{l}\text { Trophic } \\
\text { guilds }\end{array}$ & Food items & $\begin{array}{l}\% \\
\text { contribution }\end{array}$ \\
\hline \multirow[t]{8}{*}{ Dry } & \multirow[t]{3}{*}{ G 1} & Shrimp & 27.93 & \multirow[t]{15}{*}{ Hot } & \multirow[t]{3}{*}{ G 1} & Fish & 43.47 \\
\hline & & $\begin{array}{l}\text { Sergestid } \\
\text { shrimp }\end{array}$ & 27.65 & & & Zooplankton & 19.25 \\
\hline & & Fish & 13.24 & & & $\begin{array}{l}\text { Benthic } \\
\text { invertebrates }\end{array}$ & 18.40 \\
\hline & G 2 & Shrimp & 100.00 & & \multirow[t]{2}{*}{ G 2} & Zooplankton & 70.60 \\
\hline & G 3 & $\begin{array}{l}\text { Benthic } \\
\text { invertebrates }\end{array}$ & 72.39 & & & $\begin{array}{l}\text { Benthic } \\
\text { invertebrates }\end{array}$ & 20.97 \\
\hline & G 4 & Insect tissue & 77.35 & & G 3 & Zooplankton & 96.57 \\
\hline & \multirow[t]{2}{*}{ G 5} & Phytoplankton & 42.12 & & \multirow[t]{2}{*}{ G 4} & Phytoplankton & 44.31 \\
\hline & & Detritus & 38.18 & & & Detritus & 31.29 \\
\hline \multirow[t]{7}{*}{ Rain } & \multirow[t]{3}{*}{ G 1} & Fish & 33.36 & & & & \\
\hline & & Polychaete & 21.63 & & & & \\
\hline & & $\begin{array}{l}\text { Benthic } \\
\text { invertebrates }\end{array}$ & 18.07 & & & & \\
\hline & \multirow[t]{2}{*}{ G 2} & Insect tissue & 59.09 & & & & \\
\hline & & Zooplankton & 36.36 & & & & \\
\hline & G 3 & Phytoplankton & 62.13 & & & & \\
\hline & G 4 & Insect tissue & 100.00 & & & & \\
\hline
\end{tabular}

\section{Conclusion}

To conclude, omnivory and narrow dietary niche breadth are common in the Mae Klong estuary, which zooplankton formed the dominant group in fish diets. Most fishes 
are specific consumers. The diet diversity of most fish species in the Mae Klong estuary varied seasonally in their abundance in the gut contents which seems to reflect a lower or higher availability of prey where they show some seasonal preference to certain food groups: during the warm period, an abundant food supply in the estuary reduces competition; in dry period, the low densities of the main prey make a certain diversification of diet necessary. This study is a 'snapshot' view of the diets of resident fish species which can serve as a reference for feeding ecology of fish in the Mae Klong estuary and in sustainable use and management of fisheries resources in the area.

\section{Acknowledgments}

Gratitude is expressed to all the researchers, authors, and fishermen of Mae Klong for use of data and publications during the present study. Thanks to Siriwan Suksri who helped with sampling and data analysis. Thanks are also due to the Faculty of Liberal Arts and Science, Kasetsart University for funding support for participation in the ICSD 2014 conference at which this paper was presented.

\section{References}

Abrantes, K., \& Sheaves, M. (2009). Food web structure in a near-pristine mangrove area of the Australian wet tropics. Estuarine, Coastal and Shelf Science, 82, 597-607.

Alongi, D.M. (2002). Present state and future of the world's mangrove forest. Environmental Conservation, 29, 331-349.

Baldó, F., \& Drake, P. (2002). A multivariate approach to the feeding habits of small fishes in the Guadalquivir Estuary. Journal of Fish Biology, 61(Supplement A), 21-32.

Blaber, S.J.M. (1985). The ecology of fishes of estuaries and lagoons of the Indo-Pacific with particular reference to southeast Africa. In A. Yanez-Aráñcibia (Ed.), Fish community ecology in estuaries and coastal lagoons (pp. 247-266). Universidad Nacional Autónoma de México, México.

Boondao, S. (2006). Relationship between species composition and abundance of phytoplankton with zooplankton in Mae Klong Estuary, Samut Songkharm Province (Mater's thesis). Kasetsart University, Thailand.

Boonruang, P., Sawangarreruks, S., \& Pong-in, S. (1994). The community of fish and their relation to food items in the mangrove area, Phang-nga Bay (pp. 230-248). Proceedings the Seminar on Fisheries 1994. Department of Fisheries, Ministry of Agriculture and Cooperatives.

Boonruang, P., \& Satapoomin, S. (1997). The community structure of fish and their relation to food items in the mangrove area, Ranong Province. The $10^{\text {th }}$ National Seminar on Mangrove Ecology: Mangrove Management and Conservation for the Lessons in the Twenty Years Round. 25-28 August 1997, Songkla. National Research Council of Thailand.

Chong, V., Sasekumar, C., Leh, M.U.C., \& D'Cruz, R. (1990). The fish and prawn communities of a Malaysian coastal mangrove system, with comparison to adjacent mudflats and inshore waters, Estuarine, Coastal and Shelf Science, 31, 703-722.

Christensen,V., \& Pauly, D. (1998). Changes in models of ecosystems approaching carrying capacity. Ecological Applications, 8(1), 104-109.

Clarke, K.R., Warwick, R.M. (2001). (2nd ed.). Changes in marine communities: an approach to

statistical analysis and interpretation, PRIMER-E: Plymouth.

Darnell, R.M. (1962). Trophic spectrum of an estuarine community, based on studies of Lake Pontchartrain, Louisiana. Ecology, 42, 553-558.

Hajisamae, S., Chou, L.M., \& Ibrahim, S. (2003). Feeding habits and trophic organization of the fish community in shallow waters of an impacted tropical habitat. Estuarine, Coastal and Shelf Science, 58, 89-98.

Hajisamae, S., Chou, L.M., \& Ibrahim, S. (2004). Feeding habits and trophic relationships of fishes utilizing and impacted coastal habitat, Singapore. Hydrobiologia, 520, 61-71.

Hajisamae, S., Yeesin, P., \& Chaimongkol, S. (2006). Habitat utilization by fishes in a shallow, semi-enclosed estuarine bay in southern Gulf of Thailand. Estuarine, Coastal and Shelf Science, 68, 647-655.

Hajisamae, S., \& Ibrahim, S. (2008). Seasonal and spatial variations of fish trophic guilds in a shallow, semienclosed tropical estuarine bay. Environmental Biology of Fishes, 82, 251-264 
Hajisamae, S. (2009). Trophic ecology of bottom fishes assemblage along coastal areas of Thailand. Estuarine, Coastal and Shelf Science, 82, 503-514

Hammerschlag, N., Ovando, D., \& Serafy, J.R. (2010). Seasonal diet and feeding habits of juvenile fishes foraging along a subtropical marine ecotone. Aquatic Biology, 9, 279-290

Hurlbert, S. H. (1978). The measurement of niche overlap and some relatives. Ecology, 59, 67-77.

Hynes, H.B.N. (1950). The food of freshwater sticklebacks (Gasterosteus aculeatus and Pygosteus pungitius), with a review of method used in studies of the food of fishes. Journal of Animal Ecology, 19, 36-58.

Hyslop, E. J. (1980). Stomach content analysis: a review of methods and their applications. Journal of Fish Biology, 17 (4), 411-429.

Ikejima, K., Tongnunui, P., Medej, T., \& Taniuchi, T. (2003). Juveniles and small fishes in a mangrove estuary in Trang province, Thailand: Season and habitat differences. Estuarine, Coastal and Shelf Science, 56, 447-457.

Krebs, C.J. (1989). Ecological Methodology. Harper \& Row, New York.

Labropoulou, M., \& Papadopoulou-Smith, K.N. (1999). Foraging behavior patterns of four sympatric demersal fishes. Estuarine, Coastal and Shelf Science, 49, 99-108.

Le Pape, O., Jean, F., \& Menesguen, A. (1999). Pelagic and benthic model coupling, application to the Bay of Brest, a semi-enclosed zone of western Europe. Marine Ecology Progress Series, 189, 135-147.

Lugo, A.E., \& Snedaker, S.C. (1974). The ecology of mangroves. Annual Review of Ecology and Systematics, 5, 39-64.

Novakowski, G.C., Segatti, H.N., \& Fugi, R. (2008). Diet seasonality and food overlap of the fish assemblage in a pantanal pond. Neotropical Ichthyology, 6(4), 567-576.

Platell, M.E., \& Potter, I.C. (2001). Partitioning of food resources amongst 18 abundant benthic carnivorous fish species in marine waters on the lower west coast of Australia. Journal of Experimental Marine Biology and Ecology, 261, 31-54.

Poovachiranon, S., \& Satapoomin, U. (1994). Occurrence of fish fauna associated in mangrove-seagrass habitats during the wet season, Phuket, Thailand (pp.539-550) Vol. 2. In: S. Sudara, C.R. Wilkinson \& L.M. Chou (Eds.). Proceeding of the third ASEAN-Australia symposium on living coastal resources, Research paper. Chulalongkorn University, Bangkok, Thailand.

Salini, J.P., Brewer, D.T., \& Blaber, S.J.M. (1998). Dietary studies on the predatory fishes of the Norman River Estuary, with particular reference to penaeid prawns. Estuarine, Coastal and Shelf Science, 46, 837-847.

Sasekumar, A., Chong, V.C., Leh, M.U., \& D’ Cruz, R. (1992). Mangroves as a habitat for fish and prawns. Hygrobiologia, 247, 195-207.

Sasekumar, A., Chong,V.C., Lim, K.H., \& Singh, H. (1994).The fish community of Matang waters (pp.446-453) Vol. 1. In: S. Sudara, C.R. Wilkinson \& L.M. Chou (Eds.). Proceeding of the third ASEANAustralia symposium on living coastal resources, Status review. Chulalongkorn University, Bangkok, Thailand.

Sribyatta, P. (1996). Variation of zooplankton abundance in the Gulf of Thailand 1976-1994. Tech.

Paper No 4/2539. Marine Fisheries Environmental Group, Marine Fisheries Division, Department of fisheries.

Sudara,S., Satumanatpan, S., \& Nateekanjanalarp, S. (1994). Biodiversity of a newly established mangrove protected area at Samut Songkeram Province (pp.551-560) Vol. 2. In: Sudara, S., Wilkinson, C.R., Chou, L.M. (Eds.). Proceeding of the third ASEAN-Australia symposium on living coastal resources, Research paper. Chulalongkorn University, Bangkok, Thailand.

Vidthayanon, C., \& Premcharoen, S. (2002). The status of estuarine fish diversity in Thailand. Journal of Marine and Freshwater Research, 53, 471-478.

Wichitwarakhun, W. (2001). Macrobenthic fauna in forest at Baan Klong Kone, Samut Songkhram Province (Master's thesis). Chulalongkorn University, Thailand.

Wongchinawit, S. (2007). Feeding ecology of spotted scat Scatophagus argus, Linnaeus in mangrove forests, Pak Phanang Estuary, Nakhon Si Thammarat Province (PhD's thesis). Chulalongkorn University, Thailand.

Wooldridge, T. (1999). Estuarine zooplankton community structure and dynamics (pp. 141-166). In: B.R. Allanson \& D. Baird (Eds.). Estuaries of South Africa. Cambridge University Press, Cambridge.

Xie, S., Cui, Y., Zhang, T., \& Li, Z. (2000). Seasonal patterns in feeding ecology of three small fishes in the Biandantang Lake, China. Journal of Fish Biology, 57, 867-880.

Yap, Y.N., Sasekumar, A., \& Chong, V.C. (1994). Sciaenid fishes of the Matang mangrove waters (pp.551-560) Vol. 2. In: S. Sudara, C.R. Wilkinson \& L.M. Chou (Eds.), Proceeding of the third ASEAN-Australia symposium on living coastal resources, Research paper. Chulalongkorn University, Bangkok, Thailand. 